\title{
Primocane Development and Early Yield of 'Heritage' Red Raspberry in Relation to Initial Plant In-row Spacing
}

\author{
S.C. Myers ${ }^{1}$ \\ Department of Horticulture, The University of Georgia, Athens, GA 30602 \\ Additional index words. Rubus idaeus, primocane-fruiting, high-density planting
}

\begin{abstract}
Micropropagated plants of 'Heritage' primocane-fruiting (PF) red raspberry (Rubus idaeus L.) were planted at in-row spacings of 100, 50, or $25 \mathrm{~cm}$. Yield per unit area during the first season was positively correlated with initial plant in-row spacing. During the first season of growth, initial plant in-row spacing did not affect the total number of primocanes that developed but was positively associated with the numbers of primocanes that fruited. Yield per primocane, primocane yield efficiency, total nodes per primocane, and number of fruiting nodes per primocane were not affected by plant in-row spacing in the first year. Average fruit weight and fruiting primocane diameter in the first year were negatively associated with plant in-row spacing. Photosynthetic photon flux density (PPFD) penetrating the row canopy as measured in the first season was not affected by treatment. Treatment did not influence percentage of fruit exhibiting solar injury, shattering, or infection by Botrytis cinerea. Plant in-row spacing did not influence yield during the second and third production seasons.
\end{abstract}

Raspberry production based on primocane-fruiting (PF) cultivars, which fruit in late summer and fall on erect currentseason's canes, is widely established in Europe and North America (Keep, 1988). 'Heritage' is one of the most productive and widely adapted PF cultivars (Ourecky and Slate, 1969), possibly due to few negative yield component relationships compared with other PF cultivars (Hoover et al., 1988). PF cultivars offer certain cultural and economic advantages over summer-fruiting (SF) cultivars: they extend the harvest season, avoid expensive support systems, and replace labor-intensive pruning and cane selection with a single dormant mowing (Funt, 1981; Ourecky, 1976). Winter injury to canes is also avoided (Ourecky, 1976).

The full yield potential of PF raspberry cultivars is often not realized, however, particularly in cool climates, where fall freezes terminate the fruiting season or where inclement fall weather results in crop loss (Keep, 1988; Lockshin and Elfving, 1981). In warm areas, the long fall growing season results in higher yields for 'Heritage' and other PF cultivars, although yields of PF cultivars are often lower than those of SF cultivars (Keep, 1988; Stiles, 1980). The productivity of PF cultivars is further lessened by a consistent yield decline that occurs as the planting ages, possibly due to the stress of severe pruning and producing new canopy each year (Skirvin and Otterbacher, 1979).

Production systems offering high early yields would compensate for current limitations of PF culture and provide earlier returns on investment (Hoover et al., 1988). Raspberry yield components include fruit size, fruit per lateral, laterals per cane, and number of canes (Freeman et al., 1989; Hoover et al., 1988). Yield component relationships vary among SF and PF

\footnotetext{
Received for publication 16 Dec. 1991. Accepted for publication 28 May 1992. A contribution of The Univ. of Georgia Agricultural Experiment Station, College Station, Athens. This research was supported by state and Hatch funds allocated to the Georgia Agricultural Experiment Stations. Appreciation to Amy Savelle, Junior Duckworth, and Mike Duemmel for technical assistance, and to Delores White for manuscript preparation. The cost of publishing this paper was defrayed in part by the payment of page charges. Under postal regulations, this paper therefore must be hereby marked advertisement solely to indicate this fact.

${ }^{1}$ Associate Professor of Horticulture.
}

genotypes (Hoover et al., 1988). In mature SF plantings, total yield per unit area has been positively (Crandall et al., 1974a) and inconclusively (Fejer, 1979) associated with cane density. Yield per cane in SF cultivars, however, is clearly associated with cane diameter and number of laterals per cane (Crandall et al., 1974a, 1974b). Cane diameter, which increases with decreasing cane density, is positively associated with berries per lateral and total berries per cane (Crandall et al., 1974b). Increased cane density in a mature SF cultivar planting had a strong negative effect on fruit size (Nehrbas and Pritts, 1988). In Canada, Freeman et al. (1989) found that the highest-yielding mature SF cultivars generally produced the fewest canes, and these had long laterals. For lower-yielding SF cultivars, primocane removal reduced total cane count but increased fruit size and marketable yield.

Within a given tree fruit production system, early production is a function of plant density per unit area, with production increasing along with density (Ferree, 1980; Wertheim et al., 1986). High initial cane densities in raspberry may offer potential for higher early yields. With a SF cultivar in Oregon, Martin and Nelson (1987) decreased between-row spacing to give 33\% more rows per unit area. Yields increased at higher row densities. However, yield increases were inconsistent and not considered adequate to justify higher establishment cost of additional support needed for added rows. With trailing blackberry (Rubus ursinus Chan \& Schlecht), Sheets et al. (1972) obtained increased yields with closer in-row spacing. Closer spacing was considered to be economical.

Lawrence (1980) hypothesized that close in-row spacings for PF cultivars might increase yields to near that of SF cultivars. Following analysis of PF yield components, Hoover et al. (1988) suggested that high cane density, rapid development of laterals, and optimal fruit size may lead to development of early and higher yields. Hoover et al. (1988) also suggested that retention of high cane densities should increase yield without adversely affecting fruit size. The influence of initial plant spacing of $\mathrm{PF}$ cultivars on primocane development, fruit production per primocane, or fruit size is not well-established in the literature, however.

Therefore, in this study I examined yield components during the first 3 years of growth of fall-cropped 'Heritage' red rasp- 
Table 1. Yield and fruit weight of 'Heritage' red raspberry primocanes as affected by initial plant in-row spacing, Athens (1988-90).

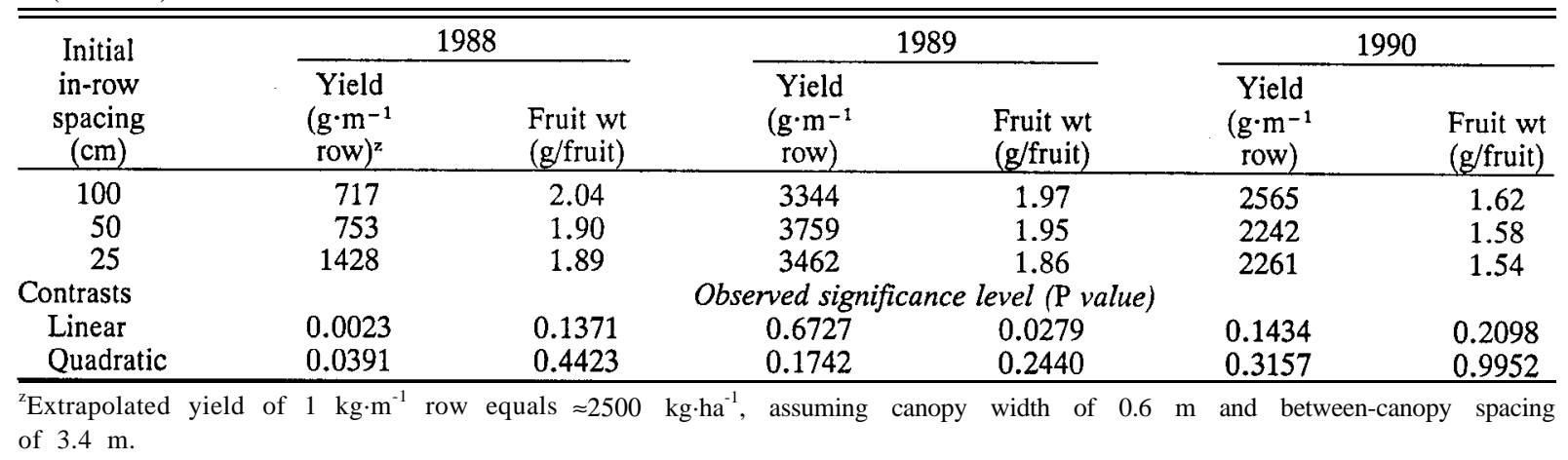

berry in relation to different plant in-row spacing established at planting.

\section{Materials and Methods}

Micropropagated, actively growing plantlets of 'Heritage' red raspberry were placed in $26.5-\mathrm{cm}^{3}$ cone-shaped containers (No. 73 Groove Tube, Growing Systems, Milwaukee) and rooted in a greenhouse in Fall 1987. Rooted plants, 5 to $7 \mathrm{~cm}$ tall with six to 10 leaves and not actively growing, were selected for uniformity and planted in Mar. 1988 at the Horticulture Research Farm in Athens, Ga., and at the Georgia Mountain Branch Station in Blairsville. Soil at both sites is a Typic Hapludult, a "Cecil sandy loam" at Athens and a "Hayesville clay loam" at Blairsville. Athens, located in the Piedmont, has a growing season of 224 days, average July temperature of $26.2 \mathrm{C}$, average first killing frost date of 8 Nov., and annual precipitation of 1274 mm (Natl. Oceanic \& Atmospheric Admin., 1982, 1988). Blairsville, located in the mountains, has a growing season of 156 days, average July temperatures of $22.5 \mathrm{C}$, average first killing frost date of 9 Oct., and annual precipitation of 1443 mm (Natl. Oceanic \& Atmospheric Admin., 1982, 1988).

Planting treatments were in-row spacings of 100, 50, or 25 $\mathrm{cm}$ in a randomized complete block design with four replications. Each experimental unit consisted of a 4-m plot, separated from adjacent plots by guard plants. Between-row spacing was $2.8 \mathrm{~m}$. The continuous spatial effects were partitioned into single-degree-of-freedom contrasts for linear and quadratic components. Inverse sine transformation was used for analysis of fruit quality percentage data.

Athens' plots were established and maintained with in-row trickle and overhead sprinkler irrigation. At Blairsville, plots were maintained entirely with overhead sprinklers. Irrigation was applied to maintain a minimum weekly precipitation of 25 $\mathrm{mm}$. Fertilization and pests were managed according to local recommendations. During the initial growing season, a postplanting application (1 Apr.) of $10 \mathrm{~N}-10 \mathrm{P}-10 \mathrm{~K}$ fertilizer at 113 $\mathrm{g} \cdot \mathrm{m}^{-1}$ of row and an additional early summer (2 June) application of $15.5 \mathrm{~N}-0 \mathrm{P}-0 \mathrm{~K}$ fertilizer at $227 \mathrm{~g} \cdot \mathrm{m}^{-1}$ of row were made in a 45.7-cm-wide band. In 1989 and 1990, rates were doubled but applied at the same time of year.

In 1988 and 1989, fruit on primocanes from each entire 4-m plot were harvested at 2- to 5-day intervals. In 1990, a 1-m section within each 4-m plot was selected and harvested at 2to 5-day intervals. In 1988 in Athens, the entire crop was weighed and fruit were counted for each harvest date. All fruit in 1988 were individually evaluated for presence of solar injury, shattering, and infection by Botrytis cinerea. A 25-fruit sample at each harvest date was used to determine fruit length and diameter in 1988. In 1989 and 1990 at Athens and during each year at the Blairsville location, a 50-fruit random sample was taken from each plot on each harvest date to determine average fruit weight.

Fruiting primocanes were tagged in 1988 at Athens to indicate date of first and last harvest. In all 3 years, number of fruiting and nonfruiting primocanes and fruiting primocane diameter (5 $\mathrm{cm}$ above ground level) were determined.

During the first and second seasons, canopy light measurements of PPFD between 400 and $700 \mathrm{~nm}$ were taken using a LI-COR LI-188B integrating quantum radiometer/photometer with a LI-COR LI-1915 line quantum sensor (LI-COR, Lincoln, Neb.) Measurements were taken in two 1-m sections within each 4-m plot at ground level and at $75 \mathrm{~cm}$ above ground level in the center of and parallel to the row. Each reading was integrated for $10 \mathrm{sec}$, and the two readings for each level were averaged. Full sun was also recorded once at each plot, as light conditions were uniform.

\section{Results}

In the year of planting and initial fruit production (1988), yield was positively related to plant in-row spacing at both sites (Tables 1 and 2). Yields were 99\% and 72\% higher in the 25$\mathrm{cm}$ spacing at the Athens and Blairsville sites, respectively, than in the $100-\mathrm{cm}$ spacing. Yields increased at both sites during the second season for all spacing treatments, but there were no yield differences associated with spacing treatments at either site during 1989 and 1990.

In the initial harvest season, individual fruit weight at Blairsville was least in the closely spaced plantings (Table 2). In Athens, 1988 fruit weight was negatively associated with plant spacing at $P=0.13$. Length : diameter ratio, a measure of fruit shape, was 0.8 for all treatments in 1988 at Athens (data not presented). The decrease in fruit weight as a result of closer plant in-row spacing had an apparent carryover effect in 1989 only at Athens.

The 1988 harvest season at Athens was from 12 Aug. to 4 Nov., a period of 12 weeks (Table 3). The harvest period at Blairsville was only 8 weeks, from 21 Aug. to 21 Oct. (data not presented). Yields at the beginning and end of the harvest season were similar among treatments. In Athens, the middle 6 weeks of harvest accounted for the yield increases due to closer initial plant in-row spacings. Similarly, the middle 4 weeks of the harvest season accounted for yield differences at Blairsville (data not presented).

Initial plant in-row spacing did not affect the date at which 
Table 2. Yield and fruit weight of 'Heritage' red raspberry primocanes as affected by initial plant in-row spacing, Blairsville (1988-90).

\begin{tabular}{|c|c|c|c|c|c|c|}
\hline \multirow{2}{*}{$\begin{array}{c}\text { Initial } \\
\text { in-row } \\
\text { spacing } \\
(\mathrm{cm})\end{array}$} & \multicolumn{2}{|c|}{1988} & \multicolumn{2}{|c|}{1989} & \multicolumn{2}{|c|}{1990} \\
\hline & $\begin{array}{l}\text { Yield } \\
\left(\mathrm{g} \cdot \mathrm{m}^{-1}\right. \\
\text { row })^{2} \\
\end{array}$ & $\begin{array}{c}\text { Fruit wt } \\
\text { (g/fruit) }\end{array}$ & $\begin{array}{l}\text { Yield } \\
\left(\mathrm{g} \cdot \mathrm{m}^{-1}\right. \\
\text { row }) \\
\end{array}$ & $\begin{array}{c}\begin{array}{c}\text { Fruit wt } \\
\text { (g/fruit) }\end{array} \\
\end{array}$ & $\begin{array}{l}\text { Yield } \\
\left(\mathrm{g} \cdot \mathrm{m}^{-1}\right. \\
\text { row } \\
\end{array}$ & $\begin{array}{c}\begin{array}{c}\text { Fruit wt } \\
(\mathrm{g} / \text { fruit) }\end{array} \\
\end{array}$ \\
\hline 100 & 603 & 2.75 & 1709 & 1.85 & 2048 & 1.68 \\
\hline 50 & 845 & 2.55 & 1729 & 1.86 & 2307 & 1.70 \\
\hline 25 & 1041 & 2.48 & 1761 & 1.85 & 2166 & 1.75 \\
\hline Contrasts & & & Observed sig & level $(\mathrm{P}$ va & & \\
\hline Linear & 0.0248 & 0.0025 & 0.7156 & 0.9338 & 0.7026 & 0.1278 \\
\hline Quadratic & 0.8603 & 0.2375 & 0.9642 & 0.7740 & 0.4623 & 0.5592 \\
\hline
\end{tabular}

${ }^{\mathrm{z}}$ Extrapolated yield of $1 \mathrm{~kg} \cdot \mathrm{m}^{-1}$ row equals $\approx 2500 \mathrm{~kg} \cdot \mathrm{ha}^{-1}$, assuming canopy width of $0.6 \mathrm{~m}$ and between-copy spacing of $3.4 \mathrm{~m}$.

Table 3. Harvest period of 'Heritage' red raspberry primocanes as affected by initial plant in-row spacing, Athens (1988).

\begin{tabular}{|c|c|c|c|c|c|c|c|c|}
\hline \multirow{2}{*}{$\begin{array}{l}\text { Initial } \\
\text { in-row } \\
\text { spacing } \\
(\mathrm{cm})\end{array}$} & \multicolumn{6}{|c|}{ 2-week yield $(\mathrm{g})^{\mathrm{z}}$} & \multirow{2}{*}{$\begin{array}{l}\text { Fruiting } \\
\text { period/ } \\
\text { plot } \\
\text { (days) }\end{array}$} & \multirow{2}{*}{$\begin{array}{c}\text { Fruiting } \\
\text { period/ } \\
\text { primo- } \\
\text { cane } \\
\text { (days) }\end{array}$} \\
\hline & 1 & 2 & 3 & 4 & 5 & 6 & & \\
\hline 100 & 10 & 117 & 201 & 211 & 100 & 78 & 74 & 44 \\
\hline 50 & 14 & 142 & 244 & 231 & 83 & 40 & 76 & 44 \\
\hline 25 & 32 & 50 & 427 & 488 & 171 & 61 & 77 & 50 \\
\hline Contrasts & \multicolumn{8}{|c|}{ Observed significance level ( $P$ value $)$} \\
\hline Linear & 0.1856 & 0.0763 & 0.0151 & 0.0004 & 0.0311 & 0.6421 & 0.5024 & 0.2504 \\
\hline Quadratic & 0.5816 & 0.4657 & 0.2786 & 0.0128 & 0.0540 & 0.3720 & 0.8215 & 0.5004 \\
\hline
\end{tabular}

${ }^{\mathrm{z}}$ Harvest period extended from 12 Aug. to 4 Nov.; total harvest period, 12 weeks. Yields per 2-week period per meter of row. Extrapolated yield of $1 \mathrm{~kg} \cdot \mathrm{m}^{-1}$ row equals $\approx 2500 \mathrm{~kg} \cdot \mathrm{ha}^{-1}$, assuming canopy width of $0.6 \mathrm{~m}$ and between-canopy spacing of $3.4 \mathrm{~m}$.

fruit began to mature on individual primocanes nor the total length of the fruiting period (Table 3 ). In addition, plant spacing also had no effect on the length of the fruiting period for individual primocanes.

Plant in-row spacing had no effect on the total number of primocanes that emerged and developed following planting in the initial 1988 season in Athens (Table 4). However, the number of primocanes that fruited per unit area of row was positively associated with plant in-row spacing. Only $20 \%$ of the total primocane population fruited in the $100-\mathrm{cm}$ spacing, compared with $40 \%$ in the $25-\mathrm{cm}$ spacing. Along with the increased number of fruiting primocanes, closer plant in-row spacing was negatively associated with primocane diameter.

The effect of initial plant spacing on the number of primocanes that fruited in 1988 recurred in 1989 in Athens. As in 1988, initial plant spacing had no effect on total number of primocanes that emerged in 1989 or 1990. Primocane di- ameter also was not affected by spacing in 1989 or 1990 at Athens.

The total number of nodes per primocane and the total number of fruiting nodes per primocane in 1988 were not affected by plant in-row spacing (Table 5). Fruit count per primocane was negatively associated with plant density at $P=0.08$. Fruit count and weight per fruiting node were highest on plants at original spacings of $50 \mathrm{~cm}$.

Total yield per primocane was similar for all plant spacing treatments in all 3 years (Table 6). In addition, primocane yield efficiency, a more relative measure of each cane's yield performance, was not affected in any year by initial plant spacing. Yield efficiency and yield per primocane appear to decline dramatically in the third season, although statistical comparisons were not made between seasons. This decline may have been due to heat and moisture stress in 1990 at Athens, and is further reflected in a decline in total yields, fruit size, and harvest

Table 4. Primocane characteristics of 'Heritage' red raspberry as affected by initial plant in-row spacing, Athens (1988-90).

\begin{tabular}{|c|c|c|c|c|c|c|c|c|c|}
\hline \multirow[b]{2}{*}{$\begin{array}{c}\text { Initial } \\
\text { in-row } \\
\text { spacing } \\
(\mathrm{cm})\end{array}$} & \multicolumn{3}{|c|}{1988} & \multicolumn{3}{|c|}{1989} & \multicolumn{3}{|c|}{1990} \\
\hline & $\begin{array}{c}\text { Primo- } \\
\text { canes/ } \\
\text { m row } \\
\text { no. }\end{array}$ & $\begin{array}{l}\text { Fruiting } \\
\text { primo- } \\
\text { canes/ } \\
\text { m row }\end{array}$ & $\begin{array}{c}\text { Fruiting } \\
\text { primo- } \\
\text { cane } \\
\text { diam } \\
(\mathrm{mm}) \\
\end{array}$ & $\begin{array}{c}\text { Primo- } \\
\text { canes/ } \\
\text { m row } \\
\text { (no.) }\end{array}$ & $\begin{array}{c}\text { Fruiting } \\
\text { primo- } \\
\text { canes/ } \\
\text { m row }\end{array}$ & $\begin{array}{l}\text { Fruiting } \\
\text { primo- } \\
\text { cane } \\
\text { diam } \\
(\mathrm{mm})\end{array}$ & $\begin{array}{c}\text { Primo- } \\
\text { canes/ } \\
\text { m row } \\
\text { (no.) }\end{array}$ & $\begin{array}{c}\text { Fruiting } \\
\text { primo- } \\
\text { canes/ } \\
\text { m row }\end{array}$ & $\begin{array}{c}\text { Fruiting } \\
\text { primo- } \\
\text { cane } \\
\text { diam } \\
(\mathrm{mm}) \\
\end{array}$ \\
\hline 100 & 10 & 2 & 11.8 & 41 & 17 & 8.5 & 37 & 27 & 9.0 \\
\hline 50 & 16 & 3 & 11.7 & 43 & 21 & 8.6 & 34 & 27 & 8.6 \\
\hline 25 & 15 & 6 & 10.1 & 41 & 20 & 8.2 & 42 & 33 & 8.9 \\
\hline Contrasts & & & & served & ficance le & (P value) & & & \\
\hline Linear & 0.1349 & 0.0015 & 0.0367 & 0.6312 & 0.0358 & 0.1094 & 0.2625 & 0.2920 & 0.8769 \\
\hline Quadratic & 0.2569 & 0.0340 & 0.2403 & 0.4379 & 0.0189 & 0.2527 & 0.1704 & 0.5634 & 0.4551 \\
\hline
\end{tabular}


Table 5. Fruiting primocane characteristics of 'Heritage' red raspberry as affected by initial plant in-row spacing, Athens (1988).

\begin{tabular}{|c|c|c|c|c|c|}
\hline $\begin{array}{l}\text { Initial } \\
\text { in-row } \\
\text { spacing } \\
(\mathrm{cm})\end{array}$ & $\begin{array}{c}\text { No d e s / } \\
\text { primocane } \\
\text { (no.) }\end{array}$ & $\begin{array}{c}\text { Fruiting } \\
\text { nodes/primo- } \\
\text { cane } \\
\text { (no.) }\end{array}$ & $\begin{array}{c}\text { Fruit/ } \\
\text { primocane } \\
\text { (no. }\end{array}$ & $\begin{array}{c}\text { Fruit/ } \\
\text { fruiting } \\
\text { node } \\
\text { no. }\end{array}$ & $\begin{array}{c}\text { Yield/ } \\
\text { fruiting } \\
\text { node } \\
\text { (g) }\end{array}$ \\
\hline 100 & 60 & 28 & 163 & 5.7 & 11.5 \\
\hline 50 & 59 & 21 & 153 & 7.6 & 14.9 \\
\hline 25 & 51 & 25 & 131 & 5.3 & 10.0 \\
\hline Contrasts & \multicolumn{5}{|c|}{ Observed significance level ( $P$ value $)$} \\
\hline Linear & 0.2241 & 0.4579 & 0.0840 & 0.6887 & 0.4078 \\
\hline Quadratic & 0.3545 & 0.2169 & 0.5110 & 0.0299 & 0.0300 \\
\hline
\end{tabular}

Table 6. Primocane yield components of 'Heritage' red raspberry as affected by initial plant in-row spacing, Athens (1988-90).

\begin{tabular}{|c|c|c|c|c|c|c|}
\hline \multirow[b]{2}{*}{$\begin{array}{l}\text { Initial } \\
\text { in-row } \\
\text { spacing } \\
(\mathrm{cm})\end{array}$} & \multicolumn{2}{|c|}{1988} & \multicolumn{2}{|c|}{1989} & \multicolumn{2}{|c|}{1990} \\
\hline & $\begin{array}{c}\text { Yield/ } \\
\text { fruiting } \\
\text { primocane } \\
(\mathrm{g})\end{array}$ & $\begin{array}{c}\text { Primocane } \\
\text { yield } \\
\text { efficiency } \\
\left(\mathrm{g} \cdot \mathrm{mm}^{-2}\right)\end{array}$ & $\begin{array}{c}\text { Yield/ } \\
\text { fruiting } \\
\text { primocane } \\
(\mathrm{g})\end{array}$ & $\begin{array}{c}\text { Primocane } \\
\text { yield } \\
\text { efficiency } \\
\left(\mathrm{g} \cdot \mathrm{mm}^{-2}\right)\end{array}$ & $\begin{array}{c}\text { Yield/ } \\
\text { fruiting } \\
\text { primocane } \\
(\mathrm{g})\end{array}$ & $\begin{array}{c}\text { Primocane } \\
\text { yield } \\
\text { efficiency } \\
\left(\mathrm{g}-\mathrm{mm}^{-2}\right)\end{array}$ \\
\hline 100 & 329 & $2.9^{z}$ & 194 & 3.4 & 95 & 1.5 \\
\hline 50 & 298 & 2.8 & 177 & 3.1 & 86 & 1.4 \\
\hline 25 & 247 & 3.1 & 175 & 3.3 & 74 & 1.2 \\
\hline Contrasts & & & Observed signifi & level ( $\mathrm{P}$ val & & \\
\hline Linear & 0.1703 & 0.0648 & 0.1736 & 0.7915 & 0.2861 & 0.1172 \\
\hline Quadratic & 0.8271 & 0.5112 & 0.4833 & 0.2544 & 0.9144 & 0.5739 \\
\hline
\end{tabular}

zPrimocane yield efficiency $=$ fruit $(\mathrm{g})$ per primocane cross-sectional area $\left(\mathrm{mm}^{2}\right)$.

period (6 weeks) in that season. Yields did not decline at Blairsville, as environmental conditions were not as limiting at that site in 1990, and the harvest period was 10 weeks long (data not presented).

The total number of fruit per row length was positively associated with plant in-row spacing in 1988 (Table 7), presumably due to more fruiting primocanes per unit area of row in the closely spaced plots. The total number of fruit that exhibited solar injury and/or shattering was higher in the closely spaced planting. However, the percentage of fruit that exhibited solar injury or shattering was similar for all treatments. Plant in-row spacing did not affect the incidence of $B$. cinerea on fruit in the initial harvest season.

At the end of the 1988 fruiting season, visible differences in canopy architecture were apparent among treatments. In the more closely spaced treatments, all primocanes were vertically oriented in the row. At the $100-\mathrm{cm}$ spacing, many primocanes developed at more horizontal orientations from the initial planting site, occupying allotted space in the row. Although closer plant in-row spacings visually appeared to affect canopy architecture, there were no differences in light penetration within the canopies among initial plant spacing treatments at Athens in 1988 (Table 8). However, the suggestion of higher light levels at ground level in the 100-cm spacing, 112 PPFD compared with 28 PPFD in the $25-\mathrm{cm}$ spacing, may be due to obvious gaps in the canopy at ground level in the wider spacing. Such gaps were not present in the $25-\mathrm{cm}$ spacing because of close plant spacing and vertical orientation of primocanes.

\section{Discussion}

The premise that closer in-row spacing might increase total yields in PF cultivars (Lawrence, 1980) is confirmed by this study. Higher primocane densities alone may not result in higher yields, however. In this study, plant in-row spacing and number of fruiting primocanes, but not total primocane density, were associated with higher yields. Closer plant in-row spacing did increase first season yields, although maturity was not advanced in any year, nor was the fruiting period of individual primocanes lengthened.

Very early in the first growing season, a constant density of primocanes per area of row was established in all spacing treatments, even though there was a $>3$-fold difference in initial

Table 7. Fruit quality of 'Heritage' red raspberry per meter of row as affected by initial plant in-row spacing, Athens (1988).

\begin{tabular}{|c|c|c|c|c|c|c|c|}
\hline \multirow{2}{*}{$\begin{array}{l}\text { Initial } \\
\text { in-row } \\
\text { spacing } \\
(\mathrm{cm})\end{array}$} & \multirow{2}{*}{$\begin{array}{l}\text { Fruit } \\
\text { (no.) }\end{array}$} & \multicolumn{2}{|c|}{ Shattered } & \multicolumn{2}{|c|}{ Solar injured } & \multicolumn{2}{|c|}{ Diseased } \\
\hline & & No. & $\%$ & No. & $\%$ & No. & $\%$ \\
\hline 100 & 352 & 13.6 & $12.0^{\mathrm{z}}$ & 16.8 & $12.4^{\mathrm{z}}$ & $9.4^{\mathrm{y}}$ & $9.3^{\mathrm{z}}$ \\
\hline 50 & 389 & 22.3 & 13.3 & 15.4 & 11.6 & 14.3 & 10.9 \\
\hline 25 & 755 & 42.6 & 13.7 & 27.4 & 10.9 & 27.1 & 10.1 \\
\hline Contrasts & \multicolumn{7}{|c|}{ Observed significance level ( $\mathrm{P}$ value) } \\
\hline Linear & 0.0025 & 0.0024 & 0.1523 & 0.0034 & 0.2853 & 0.1013 & 0.4113 \\
\hline Quadratic & 0.0577 & 0.2866 & 0.6807 & 0.0147 & 0.9389 & 0.6328 & 0.1757 \\
\hline
\end{tabular}

${ }^{\mathrm{z}}$ Inverse sine transformation used for percentage analysis.

${ }^{\mathrm{y}}$ Fruit infected with Botrytis cinerea. 
Table 8. Effect of initial plant in-row spacing on photosynthetic photon flux density (PPFD, $\mu \mathrm{mol} \cdot \mathrm{m}^{-2} \cdot \mathrm{s}^{-1}$ penetrating the canopy of 'Heritage' red raspberry, Athens (1988).

\begin{tabular}{|c|c|c|}
\hline \multirow{2}{*}{$\begin{array}{l}\text { Initial in-row } \\
\text { spacing } \\
\text { (cm) }\end{array}$} & \multicolumn{2}{|c|}{$\mathrm{PPFD}^{\mathrm{Z}}$} \\
\hline & Ground level & $75 \mathrm{~cm} \mathrm{ht}$ \\
\hline 100 & 112 & 704 \\
\hline 50 & 49 & 603 \\
\hline 25 & 28 & 668 \\
\hline Full sun & 1498 & 1498 \\
\hline Contrasts & \multicolumn{2}{|c|}{$\begin{array}{c}\text { Observed significance level } \\
\text { ( } \mathrm{P} \text { value) }\end{array}$} \\
\hline Linear & 0.2916 & 0.8380 \\
\hline Quadratic & 0.7443 & 0.5935 \\
\hline
\end{tabular}

${ }^{\mathrm{z}}$ Mean of two measurements made on 22 Sept. 1988 in the middle of the canopy parallel to row.

number of plants between the 100- and $25-\mathrm{cm}$ spacings within each 4-m plot. This constant primocane density resulted from a decrease in the number of primocanes initiated from each original plant in the $25-\mathrm{cm}$ spacing, an average of 3.5 primocanes per initial plant compared with 8.0 primocanes per initial plant in the $100-\mathrm{cm}$ spacing. Early development of a static primocane density, regardless of initial plant spacing, suggests an early root-to-root or primocane-to-primocane interaction that subsequently regulates primocane density. A sensitive regulatory mechanism is not surprising in plants such as raspberry, which naturally develop a multicaned colony. Such a mechanism might function to control allocated space and competition. However, as cane-to-cane competition increased with time, a decline in cane vigor was observed, i.e., cane diameter decreased, as previously reported (Skirvin and Otterbacher, 1979).

The suggestion that higher primocane densities should increase yields without affecting fruit size (Hoover et al., 1988) was not substantiated in this study. Closer in-row spacing at planting of PF cultivars appears to be negatively associated with fruit size, primocane diameter, and total node count, a response similar to that of SF cultivars (Crandall et al., 1974b; Nehrbas and Pritts, 1988). Presumably, the decrease in primocane vigor and fruit size was a result of cane-to-cane competition. Although year-to-year comparisons within treatments were not made, there is the suggestion of a decline in fruit size over the course of 3 years within treatments at both sites, with a concomitant increase in the number of fruiting primocanes. A decline in a number of yield components, previously observed in PF cultivars (Skirvin and Otterbacher, 1979), occurred in both sites by the third season. The decline in fruit size may be due to cumulative effects of rather high primocane densities, even with rows narrowed to $46 \mathrm{~cm}$. Colonies averaged 42 primocanes $/ \mathrm{m}$ of row in the second season in Athens. Dijkstra and van Oosten (1984) found that 16 canes/m of row is the optimum density for 'Heritage' in Holland. As such, it may be necessary to narrow 'Heritage' rows more severely or thin primocanes within each row to control primocane density.

The fruiting period and yields of the $25 \mathrm{~cm}$ spaced plantings in Athens and Blairsville (Tables 1 and 2) during the first season were similar to the fruiting period and total yields of a mature planting in Minnesota (Hoover et al., 1988). In the first year of planting, the high yields in Athens were due to the long harvest period. However, yields at Athens in the second year, nearly double the yields in the Minnesota study, may have been due to fruit maturation beginning 2 weeks earlier and extending for a longer period than in Minnesota.
High temperatures have been shown to promote cane growth and advance flowering in 'Heritage' (Lockshin and Elfving, 1981). The general vicinity of the Excelsior, Minn., site had a 151-day growing season and a first killing freeze date of 7 Oct. (G. Spoden, personal communication) compared with a 224day growing season and fall freeze date of 8 Nov. at the Athens site. During the second season at Athens, primocanes flowered, fruited, and terminated production before the fall freeze, which may provide some indication of the genetic yield potential of 'Heritage'. Second-season yields of 'Heritage' at Athens were similar to yields reported for mature plantings of SF cultivars (Nehrbas and Pritts, 1988). Thus, the opinion that yields of PF cultivars are lower than those of SF cultivars (Keep, 1988) is based on environmental rather than genetic limitation. Length of growing season and dates of fall freezes were more similar between the Blairsville and Excelsior sites. Therefore, yields and harvest season were more similar.

In areas with early fall freezes, more closely spaced plantings that have more fruiting primocanes in the initial season would realize higher yields. However, under treatments and conditions in this study, the yield effect of close plant in-row spacing would occur only in the initial growing season. Given the fixed nature of most costs of PF culture and absence of support systems, the economic feasibility of high-density plantings of 'Heritage' red raspberry would largely depend on plant cost and fruit value.

\section{Literature Cited}

Crandall, P.C., D.F. Allmendinger, J.D. Chamberlain, and K.A. Biderbost. 1974a. Influence of cane number and diameter, irrigation, and carbohydrate reserves on the fruit number of red raspberries. J. Amer. Soc. Hort Sci. 99:524-526.

Crandall, P.C., J.D. Chamberlain, and K.A. Biderbost. 1974b. Cane characteristics associated with berry number of red raspberry. J. Amer. Soc. Hort. Sci. 99:370-372.

Dijkstra, J. and A.A. van Oosten. 1984. Culture experiments with raspberries and currants. Cultivar testing of raspberries, blackberries, gooseberries and currants. Rpt. Wilhelminadorp Res. Sta. Fruit Growing, Wilhelminadorp, The Netherlands. p. 43-49.

Fejer, S.O. 1979. Note on the effects of cane density in red raspberry. Gartenbauwissenschaft 44:S. 136-137.

Ferree, D.C. 1980. Canopy development and yield efficiency of 'Golden Delicious' apple trees in four orchard management systems. J. Amer. Soc. Hort. Sci. 105:376-380.

Freeman, J.A., G.W. Eaton, T.E. Baumann, H.A. Daubeny, and A. Dale. 1989. Primocane removal enhances yield components of raspberries. J. Amer. Soc. Hort. Sci. 114:6-9.

Funt, R.C. 1981. Economic comparison of June-bearing and a fallbearing system of red raspberry culture. Rpt. Michigan State Hort. Soc. 111:156-160.

Hoover, E., J. Luby, D. Bedford, and M. Pritts. 1988. Vegetative and reproductive yield components of primocane-fruiting red raspberries. J. Amer. Soc. Hort. Sci. 113:824-826.

Keep, E. 1988. Primocane (autumn)-fruiting raspberries: a review with particular reference to progress in breeding. J. Hort. Sci. 63:1-18.

Lawrence, F.J. 1980. Breeding primocane-fruiting red raspberries for machine harvest. Annu. Rpt. Oregon Hort. Soc. 71:102-104.

Lockshin, L.S. and D.C. Elfving. 1981. Flowering response of 'Heritage' red raspberry to temperature and nitrogen. HortScience 16:527528 .

Martin, L.W. and E. Nelson. 1987. Mechanical harvest of red raspberry as affected by training systems. HortScience 22:400-401.

National Oceanic and Atmospheric Administration. 1982. Monthly normals of temperature, precipitation, and heating and cooling degree days 1951-80-Georgia. Natl. Oceanic and Atmospheric Admin., Climatology of the U.S. Suppl. No. 81, Natl. Climatic Data Ctr., Asheville, N.C. 
National Oceanic and Atmospheric Administration. 1988. Freeze/frost data. Natl. Oceanic and Atmospheric Admin., Climatology of the U.S. No. 20; Suppl. No. 1. Natl. Climatic Data Ctr., Asheville, N.C.

Nehrbas, S.R. and M.P. Pritts. 1988. Effect of training system on performance of hand-harvested summer-bearing raspberries. HortScience 23:126-127.

Ourecky, D.K. 1976. Fall-bearing red raspberries, their future and potential. Acta Hort. 60:135-144.

Ourecky, D.K. and G.L. Slate. 1969. Heritage. A new fall-bearing red raspberry. N.Y. State Agr. Expt. Sta., Res. Circ. 19.
Sheets, W.A., R.M. Bullock, and R. Garren, Jr. 1972. Effects of plant density, training and pruning on blackberry yield. J. Amer. Soc. Hort. Sci. 97:262-264.

Skirvin, R.M. and A.G. Otterbacher. 1979. Effects of single and double cropping on yields of fall bearing raspberries. Fruit Var. J. 33:144-148. Stiles, H.D. 1980. Yield and harvest season of three red raspberry cvs. in the fall-fruit-only system of management. Fruit Var. J. 34:89-91.

Wertheim, S.J., A. deJager, and M.J.J.P. Duyzens. 1986. Comparison of single row and multi-row planting systems with apple, with regard to productivity, fruit size and color, and light comparisons. Acta Hort. 160:243-258. 